Article

\title{
Assessment of Potential Capacity Increases at Combined Heat and Power Facilities Based on Available Corn Stover and Forest Logging Residues
}

\author{
Selvarani Radhakrishnan ${ }^{1}$, Joel O. Paz ${ }^{1, *}$, Fei Yu ${ }^{1}$, Sandra Eksioglu ${ }^{2}$ and Donald L. Grebner ${ }^{3}$ \\ 1 Department of Agricultural and Biological Engineering, Mississippi State University, \\ 130 Creelman St., Mississippi State, MS 39762, USA; E-Mails: selvarani.anandi@gmail.com (S.R.); \\ fyu@abe.msstate.edu (F.Y.) \\ 2 Department of Industrial and Systems Engineering, Mississippi State University, \\ 260Q McCain Engineering Building, Mississippi State, MS 39762, USA; \\ E-Mail: sde47@ise.msstate.edu \\ 3 Department of Forestry, Mississippi State University, 105 Thompson Hall, Mississippi State, \\ MS 39762, USA; E-Mail: dgrebner@cfr.msstate.edu \\ * Author to whom correspondence should be addressed; E-Mail: jpaz@abe.msstate.edu; \\ Tel.: +1-662-325-3282; Fax: +1-662-325-3853.
}

Received: 4 July 2013; in revised form: 14 August 2013 / Accepted: 15 August 2013 /

Published: 26 August 2013

\begin{abstract}
Combined Heat and Power (CHP) production using renewable energy sources is gaining importance because of its flexibility and high-energy efficiency. Biomass materials, such as corn stover and forestry residues, are potential sources for renewable energy for CHP production. In Mississippi, approximately 4.0 MT dry tons of woody biomass is available annually for energy production. In this study, we collected and analyzed 10 years of corn stover data (2001-2010) and three years of forest logging residue data $(1995,1999$, and 2002) in each county in Mississippi to determine the potential of these feed stocks for sustainable CHP energy production. We identified six counties, namely Amite, Copiah, Clarke, Wayne, Wilkinson and Rankin, that have forest logging residue feedstocks to sustain a CHP facility with a range of capacity between 8.0 and 9.8 MW. Using corn stover alone, Yazoo and Washington counties can produce 13.4 MW and 13.5 MW of energy, respectively. Considering both feedstocks and based on a conservative amount of 30\% available forest logging residue and 33\% corn stover, we found that 20 counties have adequate supply for a CHP facility with a capacity of $8.3 \mathrm{MW}$ to 19.6 MW.
\end{abstract}


Keywords: combined heat and power; sustainability; corn stover; forest logging residue; GIS

\section{Introduction}

Combined heat and power is a concurrent process, and generates heat and electricity from the same location where they need to be utilized. CHP can produce heat from any fuel source such as natural gas, biomass, biogas and coal. CHP can be applicable for various types of existing technologies for generating electricity, power, and waste-heat recovery for heating, cooling and thermal applications [1]. The two most common types of CHP systems are gas turbines and steam turbines. In a gas turbine or reciprocating engine system, the CHP system produces electricity by burning fuel and a heat recovery unit is used to capture heat from the gas turbine. In a steam turbine system, the CHP system produces steam by burning a fuel and heating water to produce steam and this is used to generate electricity in a turbine. Steam turbine-based CHP systems typically use solid fuels like coal, biomass and waste products that are readily available to fuel the boiler unit [2]. CHP is an efficient and clean way of producing power and thermal energy. The total CHP system efficiencies for producing electricity and thermal energy range from $60 \%$ to $80 \%$, which are higher than the average efficiency of conventional power plants $(33 \%)$ in the United States. These CHP efficiency gains improve the economics, as well as have other environmental benefits [2].

Forestry is the biggest source for Mississippi's economy [3]. It covers 18 million acres or $62 \%$ of the total land area in Mississippi. In Mississippi, about four million dry tons of woody biomass is available for energy production, distributed into four major types namely, logging residues (70\%), small diameter trees $(20 \%)$, urban wastes (7\%), and mill residues (3\%) [4]. Logging residues represent a significant feedstock that can be utilized for energy production, and it is less expensive than small diameter trees. In addition to forest residues, Mississippi has other types of biomass feedstock such as corn that can be used for CHP production. According to the National Agricultural Statistics Service [5] corn production in Mississippi increased significantly from 0.9 MT in 2006 to 3.4 MT in 2007. Corn acreages and corn productivity grew dramatically from 1940 to 2010 [5,6]. According to a Mississippi Agricultural and Forestry Experiment Station report [7], Mississippi farmers have grown about 280,852 ha of corn and produced 2.3 MT over the last five years. In the past 20 years corn yield doubled and are increasing faster than any other crop grown in Mississippi.

The main objectives of this study were to: (a) assess the use of corn stover and forest logging residues as distributed feedstock sources for combined heat and power facilities in Mississippi; (b) determine the potential capacity of CHP plants that can run with available biomass; and (c) quantify the sustainable amount of feedstock that can support two biomass-based CHP facilities in Mississippi. 


\section{Materials and Methods}

\subsection{Study Area}

The analysis of available biomass feedstock for CHP application focused on existing CHP facilities or plants in Mississippi. There are 22 CHP facilities in the state of Mississippi that generate a total of 570.4 MW [8-10]. The applications of these units range from dairy facilities with a capacity of $50 \mathrm{~kW}$ to oil refineries with a capacity up to $146.9 \mathrm{MW}$. Eight CHP facilities with lower capacities ( $<5 \mathrm{MW})$ are fueled by either wood, wood waste or other biomass sources. Two biomass-based CHP plants located in Mississippi, one with the lowest capacity (1 MW) and one with the highest capacity (5 MW), were selected for this study. The capacity of these CHP plants in Scott County and Washington County is $1 \mathrm{MW}$ and $5 \mathrm{MW}$, respectively (Figure 1).

Figure 1. Map showing the location of the CHP plants considered in this study.

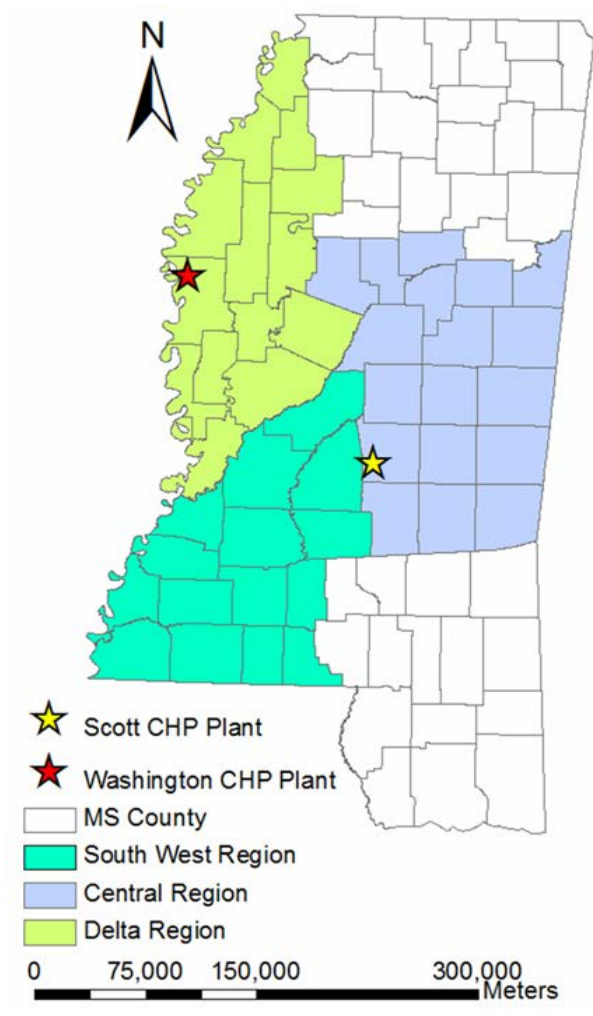

\subsection{Available Biomass}

Ten years of corn production data (2001-2010) in each county in Mississippi were collected and analyzed to determine the potential of this feedstock for sustainable CHP energy production. Corn production values were obtained by averaging the county production of corn in terms of total bushels produced for the years 2001-2010 [5]. Corn production was summed across all Mississippi counties and converted from bushels to tons [11]. Dry weight of corn grain is $720.8 \mathrm{~kg}$ per cubic meter (56 pounds per bushel) [12]. For this study, one ton of corn stover was produced for every ton of harvested corn grain, based on values reported by [12,13]. The amount of corn stover that can be collected in a sustainable way depends on different factors such as type and sequence of collection 
operations, the efficiency of the collection equipment, environmental restrictions, such as the need to control erosion, maintain soil productivity and soil carbon levels. Wyman and Hinman stated that 58\% of the corn stover could be collected on a sustainable basis [14]. Scechinger and Hettenhaus [15] suggested lower rates ranging from $40 \%$ to $50 \%$, while Brechbill [16] noted that a $53.5 \%$ utilization rate was sustainable. A conservative value of $33 \%$ collection rate of stover was used in this study, similar to the value used by Perlack [12]. The moisture content of corn stover was assumed to be $47 \%$ [17]. The available corn for energy production was calculated using Equation (1):

$$
\text { Corn stover }(\text { dry tons })=\text { Corn production }(\text { in wet tons }) \times 0.33 \times 0.53
$$

County level dry logging residue data from 1995, 1999, and 2002 were obtained from the Department of Forestry, Mississippi State University. The data were part of an inventory conducted by Periz-Verdin [4] who drew from two main sources, namely, the Mississippi Institute for Forestry Inventory (MIFI) satellite imagery-based data, and Forestry Inventory Analysis (FIA) Timber Products Output database (TPO) forest inventory data. The quantity of logging residues was based on the FIA-TPO forest inventory data as reported by the Southern Research Station. Periz-Verdin [4] converted the average volume of logging residues into dry tons using density values for pine and hardwoods of 0.507 and 0.61 dry $\mathrm{t} \mathrm{m}^{-3}$, respectively, for each county. The density values were obtained from a previous study by Gan and Smith [18]. According to Perlack [19], not all logging residues are available for bioenergy conversion. Based on this study, it was assumed $65 \%$ of $\operatorname{logging}$ residues are removed during the harvest of conventional products. The removal or collection of the logging residue impacts the soil nutrients and rate of soil erosion [20]. An optimal amount of biomass that varies between 0.8 and $2.2 \mathrm{t}$ per ha per rotation period, depending on the region and local conditions, should be left on the soil to compensate for the extraction of essential nutrients (e.g., calcium, magnesium, potassium, and phosphorus) [21]. Periz-Verdin [4] found that the resulting biomass left on site was greater than the amount recommended by Borjesson [21]. After $65 \%$ of logging residues were recovered from timber harvesting, the percentage of biomass (35\%) left in the field serves as soil nutrient.

\subsection{Biomass Conversion}

Different percentages of available corn stover and forest logging residue for CHP use were evaluated. Several corn stover (CS) and forest logging residue (FLR) utilization rates ranging from $2 \%$ to $33 \%$ were considered in this study (Figures 2 and 3). The maximum rates for available corn stover and forest logging residue were $33 \%$ and $30 \%$, respectively. High Energy Heating Values (HHV) for corn stover and logging residue were set at $17.58 \mathrm{MJ} / \mathrm{kg}(7560 \mathrm{BTU} / \mathrm{lb})$ and $19.93 \mathrm{MJ} / \mathrm{kg}$ (8570 BTU/lb), respectively [2,22]. The energy produced using corn stover and forest logging residue was calculated for each county. Viana [23] found that a typical CHP plant operated for a total of $8000 \mathrm{~h}$ a year or 333 days a year. For this study, the CHP plants in Scott and Washington counties were assumed to be in operation $24 \mathrm{~h}$ a day, 340 days a year and $8160 \mathrm{~h}$ per year. These values were slightly higher than the operational hours reported by Viana [23]. The total CHP energy efficiency was assumed at $70 \%$ [2]. 
Figure 2. The capacities of the CHP plant in Scott county based on different utilization rates (\%) of biomass feedstock. "---" Represents the existing capacity of the CHP plant in Scott county (1 MW).

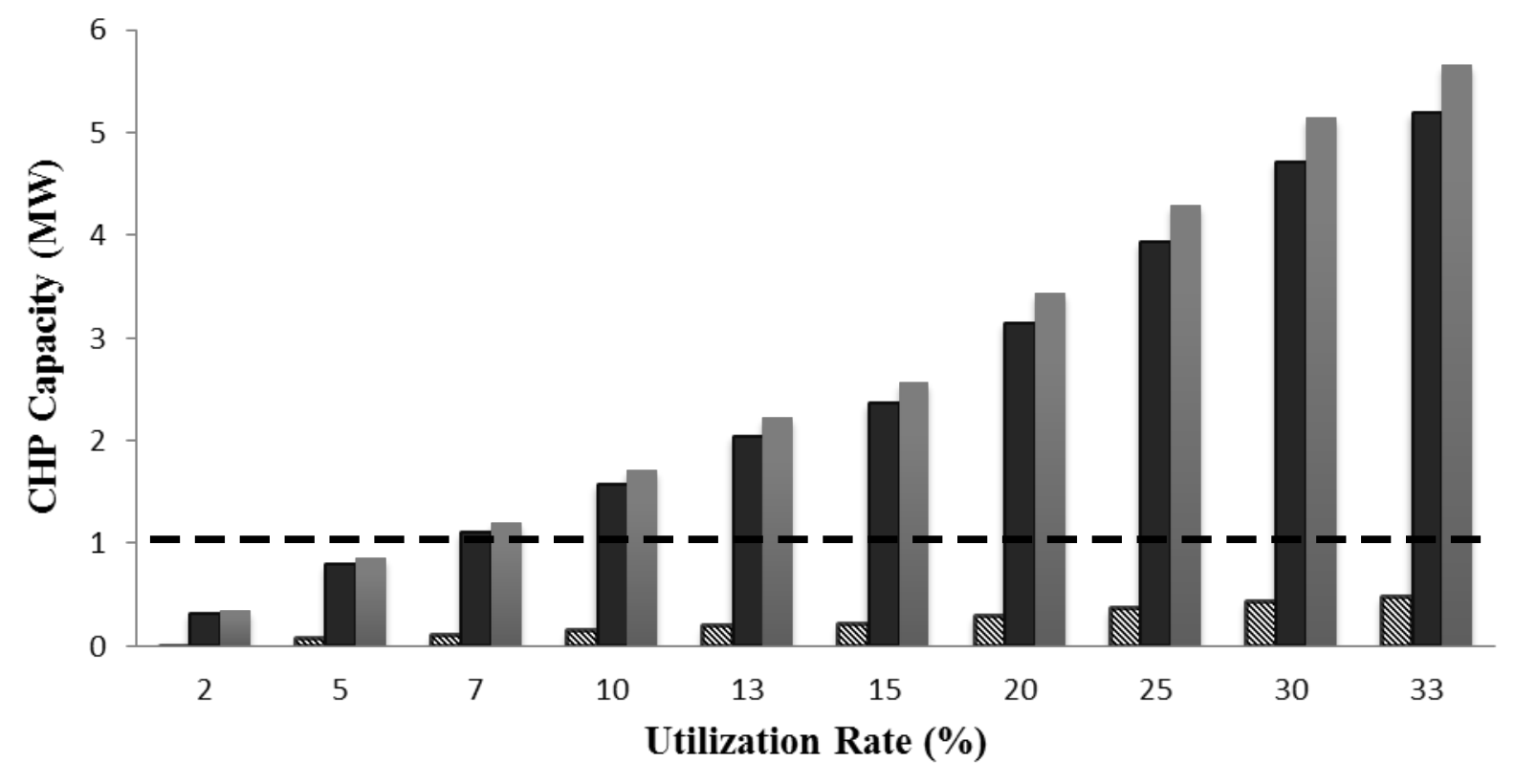

QCS IFLR $\triangle \mathrm{CS} \&$ FLR

Figure 3. The capacities of the CHP plant Washington county calculated based on different utilization rates (\%) of biomass feedstock. "---" Represents the existing capacity of the CHP plant in Washington county (5 MW).

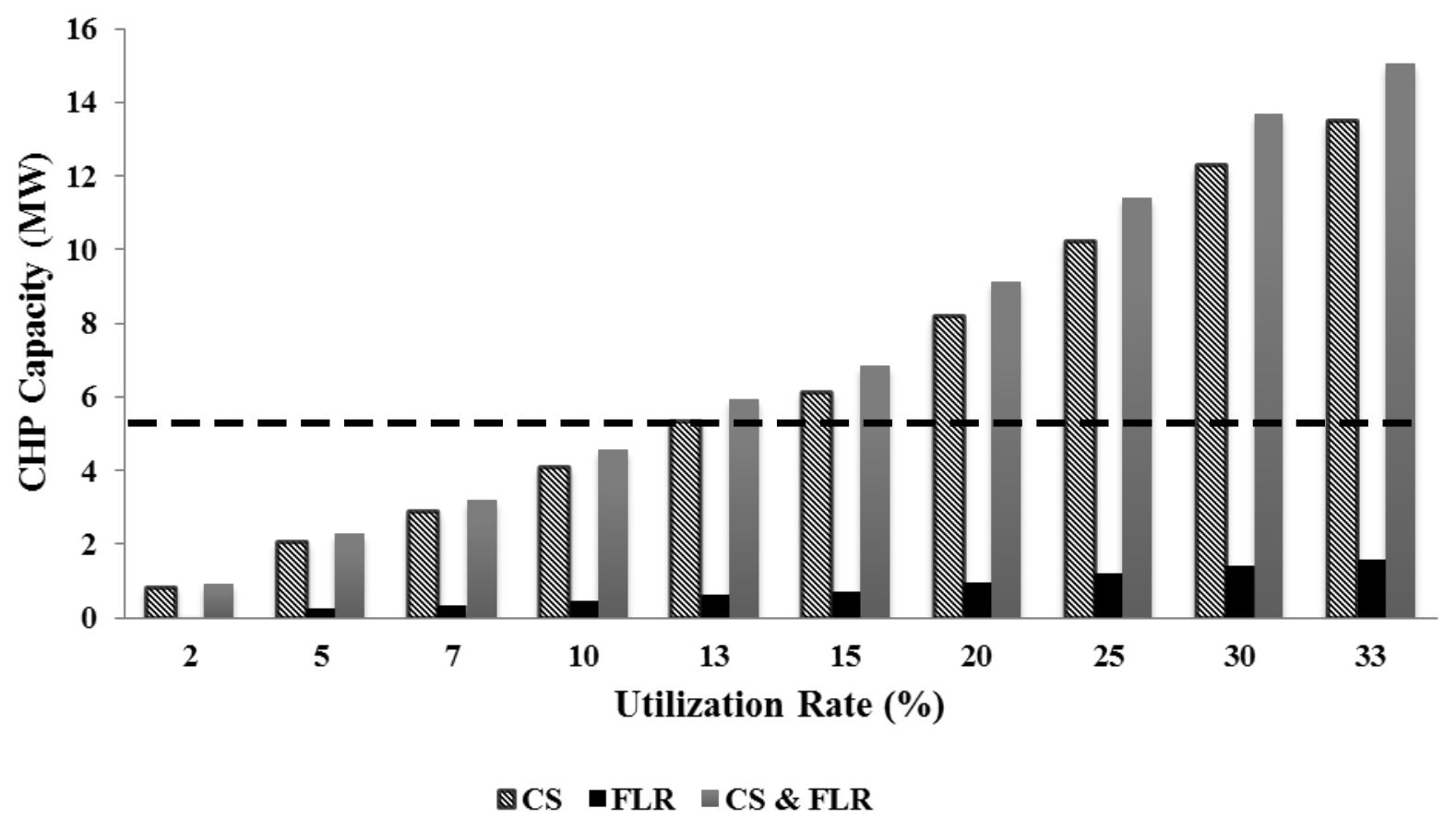

Equation (2) was used to calculate the CHP power rating based on the energy content of feedstock (corn stover or forest logging residue): 
Power Rating $=$ Feedstock Quantity $\times$ Energy Content of feedstock $\times$ CHP efficiency

One dry ton per day of logging residue can produce $0.15 \mathrm{MW}$ of CHP energy, while one ton per day of corn stover can produce $0.13 \mathrm{MW}$.

\section{Results and Discussion}

The top five Mississippi counties in terms of available forest logging residue are listed in Table 1. Each of the five counties is covered by forest area that is $80 \%$ to $86 \%$ of the county area. Thus, these five counties are predominately covered by forest and the high percentage of forest land is reflected in the logging residue available in these counties (Figure 4). The top five counties can each produce at least $8.3 \mathrm{MW}$ of CHP power from utilizing $30 \%$ of available forest logging residues (Table 1). The available logging residue tons ranged from 188 to $222 \mathrm{t}$ per day.

Table 1. Top 5 Mississippi counties in terms of available forest logging residue and their potential CHP capacities.

\begin{tabular}{cccc}
\hline County & FLR (t/day) & FLR Utilization Rate at 30\% (t/day) & FLR (MW) \\
\hline Amite & 222 & 67 & 9.8 \\
Copiah & 219 & 66 & 9.6 \\
Clarke & 218 & 66 & 9.6 \\
Wayne & 212 & 64 & 9.3 \\
Wilkinson & 188 & 56 & 8.2 \\
\hline
\end{tabular}

Notes: Forest Logging Residue (FLR), utilization rate (UR).

Figure 4. County-level potential CHP capacities (MW) for Mississippi based on 30\% utilization of forest logging residue.

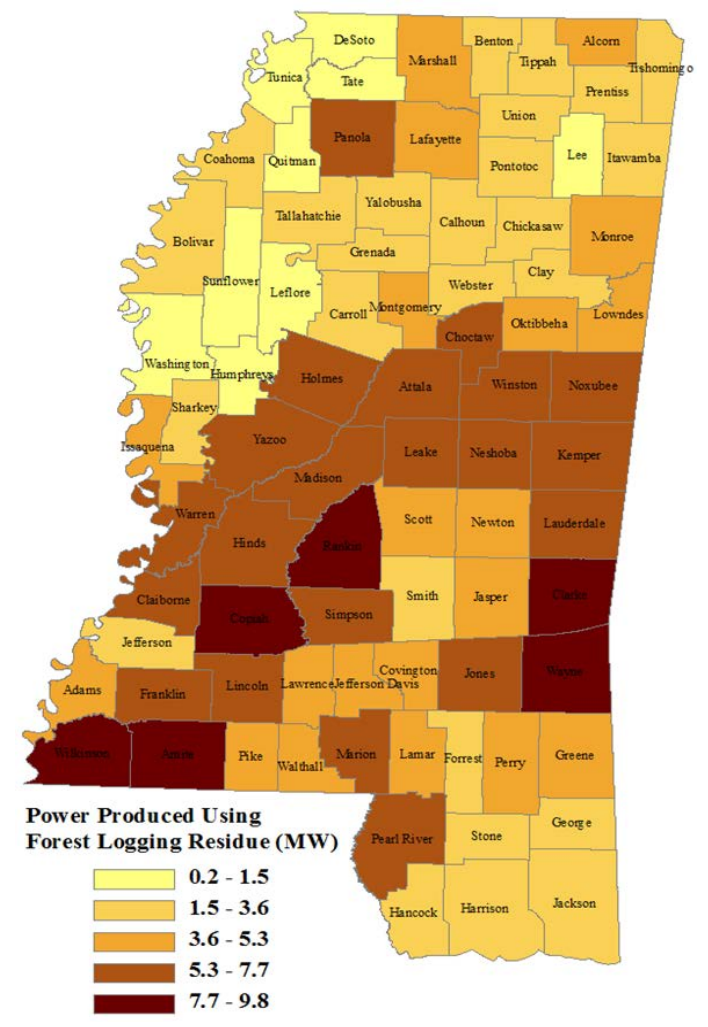


There are 20 counties in Mississippi that can each produce $8 \mathrm{MW}$ or higher CHP power based on combined utilization of corn stover and forest logging residue (Table 2). The distribution of these counties is shown in Figure 5. Yazoo County had the highest amount of available feedstock for CHP production, and its potential CHP capacity was estimated at 19.6 MW. The potential county-level CHP capacities, based on combined utilization of corn stover and forest logging residue, range from 1.8 MW to 19.6 MW (Figure 6).

Table 2. Counties with potential CHP capacity of more than $8 \mathrm{MW}$ based on combined use of corn stover and forest logging residue.

\begin{tabular}{cccccc}
\hline County & $\begin{array}{c}\text { CS } \\
\text { (t/day) }\end{array}$ & $\begin{array}{c}\text { CHP CS } \\
(\mathbf{M W})\end{array}$ & $\begin{array}{c}\text { FLR } \\
(\mathbf{t} / \mathbf{d a y})\end{array}$ & $\begin{array}{c}\text { CHP FLR } \\
\text { (MW) }\end{array}$ & $\begin{array}{c}\text { CHP CS \& FLR } \\
\text { (MW) }\end{array}$ \\
\hline Yazoo & 594 & 13.4 & 140 & 6.1 & 19.6 \\
${ }^{+}$Washington & 597 & 13.5 & 32 & 1.4 & 14.9 \\
Noxubee & 279 & 6.3 & 124 & 5.5 & 11.8 \\
${ }^{+}$Issaquena & 285 & 6.5 & 98 & 4.3 & 10.8 \\
Holmes & 198 & 4.5 & 139 & 6.1 & 10.6 \\
${ }^{+}$Sharkey & 355 & 8.0 & 54 & 2.4 & 10.4 \\
Leflore & 393 & 8.9 & 34 & 1.5 & 10.4 \\
${ }^{\#}$ Amite & 0 & 0.0 & 222 & 9.8 & 9.8 \\
Madison & 157 & 3.5 & 141 & 6.2 & 9.7 \\
Tallahatchie & 316 & 7.2 & 57 & 2.5 & 9.6 \\
${ }^{\#}$ Copiah & 0 & 0.0 & 219 & 9.6 & 9.6 \\
${ }^{*}$ Clarke & 0 & 0.0 & 218 & 9.6 & 9.6 \\
Warren & 108 & 2.4 & 162 & 7.1 & 9.5 \\
${ }^{\#}$ Wayne & 0 & 0.0 & 212 & 9.3 & 9.3 \\
Panola & 88 & 2.0 & 166 & 7.3 & 9.3 \\
${ }^{+}$Bolivar & 315 & 7.1 & 49 & 2.1 & 9.3 \\
${ }^{+}$Sunflower & 396 & 9.0 & 4 & 0.2 & 9.1 \\
Hinds & 96 & 2.2 & 156 & 6.9 & 9.0 \\
Rankin & 30 & 0.7 & 183 & 8.0 & 8.7 \\
${ }^{+}$Wilkinson & 0 & 0.0 & 188 & 8.3 & 8.3 \\
\hline
\end{tabular}

Notes: Corn stover (CS) utilization rate was assumed to be $33 \%$ and forest logging residue (FLR) utilization level was assumed to be $30 \%$; ${ }^{+}$Counties which are located in the delta region; ${ }^{*}$ Counties which are produce CHP power more than $8 \mathrm{MW}$, utilizing only forest logging residue.

The CHP facility in Washington County has an existing capacity of $5 \mathrm{MW}$. In this study, we found that the CHP plant in Washington County can be operated with just a 13\% corn stover utilization level (Table 3). The $1 \mathrm{MW}$ capacity CHP plant in Scott County can be operated with a 7\% forest logging residue utilization level within the county, but would require using corn stover at $7 \%$ utilization level from four adjacent counties (Table 3). In Washington County, it was possible to increase the capacity of the CHP plant from 5 MW to $13.5 \mathrm{MW}$ by using a sustainable CS utilization level of 33\% (Table 4). Similarly in Scott County, a 30\% FLR utilization level could potentially increase the capacity of the CHP plant from 1 MW to 4.7 MW (Table 4). The capacities of CHP plants in Scott and Washington counties could increase to $5.2 \mathrm{MW}$ and $14.9 \mathrm{MW}$, respectively, by combining both types of feedstock. 
Figure 5. Top 20 counties in Mississippi with a potential capacity of more than $8 \mathrm{MW}$ based on combined use of corn stover and forest logging residue.

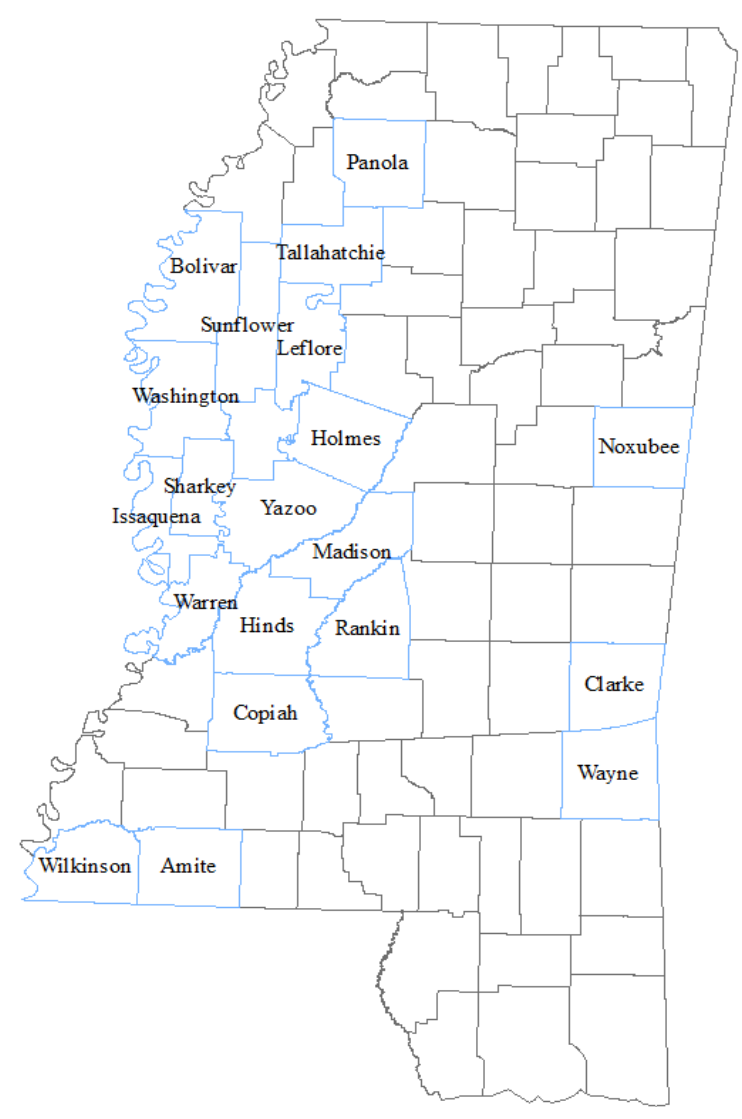

Figure 6. County-level potential CHP capacities (MW) for Mississippi based on combined use of corn stover (33\%) and forest logging residue (30\%).

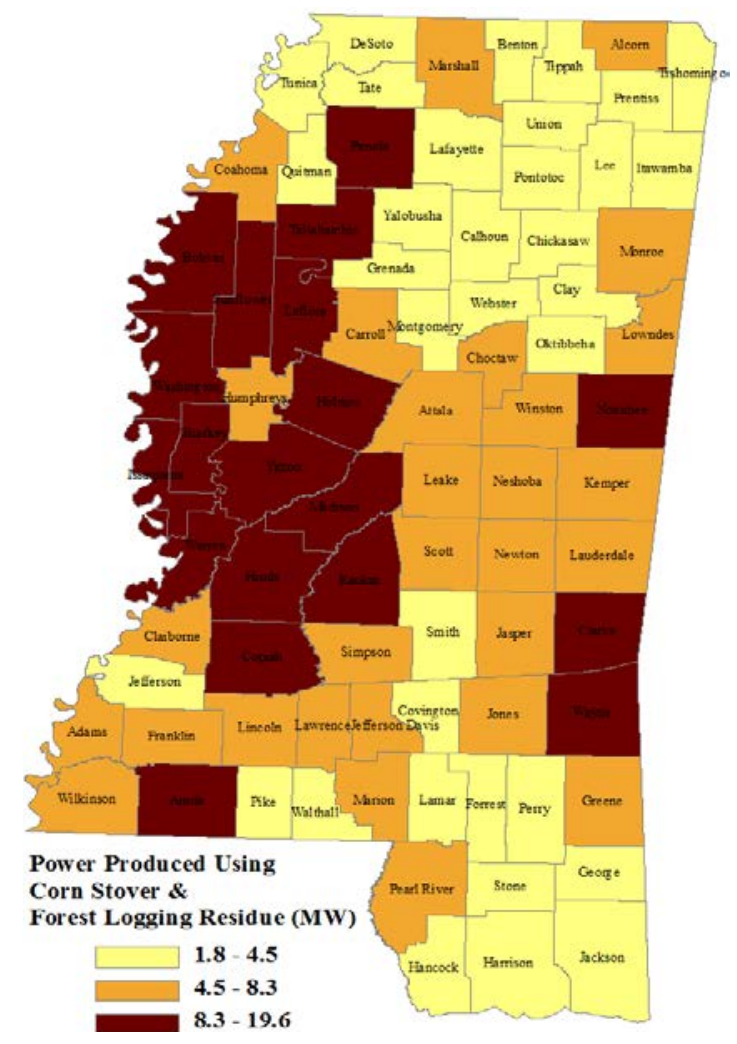


Table 3. Counties with existing CHP facilities, available biomass and required utilization levels to support current CHP capacity.

\begin{tabular}{ccccc}
\hline CHP plant (MW) & CS (t/day) & FLR (t/day) & $\begin{array}{c}\text { RUR CS CHP } \\
\text { capacity (\%) }\end{array}$ & $\begin{array}{c}\text { RUR FLR CHP } \\
\text { capacity (\%) }\end{array}$ \\
\hline Washington (5 MW) & 597 & 32 & 13 & $15^{*}$ \\
Scott (1 MW) & 21 & 107 & $7 * *$ & 7 \\
\hline
\end{tabular}

Notes: Required utilization rate (RUR), Forest logging residue (FLR), Corn stover (CS); Forest Logging Residue supply was calculated as an average supply of 1995, 1999, and 2002; * There is not sufficient logging residue in Washington County to operate a $5 \mathrm{MW}$ plant. However, combining the FLR in 4 adjacent counties at $15 \%$ utilization rate will be sufficient to support a $5 \mathrm{MW}$ plant; Corn stover supply was calculated as an average supply of 2001 to 2010; ** There is not sufficient corn stover in Scott County to operate a $1 \mathrm{MW}$ plant; However, combining the CS in four adjacent counties at $7 \%$ utilization rate will be sufficient to support a $1 \mathrm{MW}$ plant.

Table 4. Potential capacities of CHP plants in Washington and Scott based on higher utilization rates of corn stover and forest logging residue feedstock.

\begin{tabular}{cccc}
\hline $\begin{array}{c}\text { CHP plant capacity } \\
\text { (MW) }\end{array}$ & $\begin{array}{c}\text { CS CHP capacity } \\
\text { (MW) }\end{array}$ & $\begin{array}{c}\text { FLR CHP capacity } \\
\text { (MW) }\end{array}$ & $\begin{array}{c}\text { CS \& FLR CHP capacity } \\
\text { (MW) }\end{array}$ \\
\hline Washington (5) & 13.5 & 1.4 & 14.9 \\
Scott (1) & 0.5 & 4.7 & 5.2 \\
\hline
\end{tabular}

Notes: Based on 30\% utilization of FLR and 33\% utilization of CS.

\section{Conclusions}

The potential increase in CHP capacity was assessed based on a sustainable utilization rate of available corn stover and forest logging residue in Mississippi. The results show that the available corn stover is $2.0 \mathrm{MT} / \mathrm{year}$, and forest logging residues is $2.8 \mathrm{MT} / \mathrm{year}$. The total amount of available biomass feedstock is $4.8 \mathrm{MT} / \mathrm{year}$, which represents a significant amount of renewable resource that can be utilized for CHP production in Mississippi. In this study, a sustainable corn stover utilization rate of $33 \%$ can produce up to $126.9 \mathrm{MW}$ and sustainable forest logging residue utilization rate of $30 \%$ can produce 332.7 MW of power using CHP. The Mississippi Delta region is the main source for corn stover, while the southwest region of Mississippi has more forested areas, which can be tapped for energy production.

\section{Acknowledgement}

This material is based upon work supported by the U.S. Department of Energy under Award Number: DE-FC26-08NT01923.

\section{Conflicts of Interest}

The authors declare no conflict of interest. 


\section{References}

1. Hinnells, M. Combined heat and power in industry and buildings. Energy Policy 2008, 36, $4522-4526$.

2. Environmental Protection Agency. Catalogue of CHP Technologies; Environmental Protection Agency: Washington, DC, USA, 2012. Available online: http://www.epa.gov/chp/technologies.html (accessed on 10 May 2012).

3. Munn, I.A.; Tilley, B.K. The Impact of the Forest Products Industry on the Mississippi Economy: An Input-Output Analysis. In Forestry in Mississippi; Forest and Wildlife Research Center, Mississippi State University: Starkville, MS, USA, 2005.

4. Perez-Verdin, G.; Grebner, D.L.; Sun, C.; Munn, I.A.; Schultz, E.B.; Matney, T.G. Woody biomass availability for bioethanol conversion in Mississippi. Biomass Bioenergy 2009, 33, 492-503.

5. USDA-NASS. National Agricultural Statistics Service, 2012. Available online: http://quickstats.nass.usda.gov/results/012FF1F0-CB20-315E-9ED5-947848B06356. (accessed on 10 May 2012).

6. Woli, P.; Paz, J.O. Analyzing the Effect of Variations in Soil and Management Practices on the Sustainability of Corn Stover-Based Bioethanol Production in Mississippi; American Society of Agricultural and Biological Engineers: St. Joseph, MI, USA, 2011.

7. MSU Cares. Mississippi Corn Production, 2012. Available online: http://msucares.com/ crops/corn (accessed on 10 May 2012).

8. Energy and Environmental Analysis Inc. Combined Heat and Power Database, 2012a; Energy and Environmental Analysis Inc.: Washington, DC, USA, 2012. Available online: http://www.eeainc.com/chpdata/index.html (accessed on 8 May 2012).

9. Energy and Environmental Analysis Inc. Combined Heat and Power Units Located in Mississippi, 2012b; Energy and Environmental Analysis Inc.: Washington, DC, USA, 2012. Available online: http://www.eea-inc.com/chpdata/States/MS.html (accessed on 8 May 2012).

10. Energy Information Administration, 2012. Available online: http://www.eia.doe.gov/ (accessed on 8 May 2012).

11. Larson, W.E.; Holt, R.F.; Carlson, C.W. Residues for Soil Conservation. In Crop Residue Management Systems; American Society of Agronomy Special Publication, Number 31; American Society of Agronomy-Crop Science, Society of America-Soil Science Society of America: Madison, WI, USA, 1978; pp. 1-15.

12. Perlack, R.D.; Turhollow, A.F. Assessment of Options for the Collection, Handling, and Transport of Corn Stover; Oak Ridge National Laboratory: Oak Ridge, TN, USA, 2002.

13. Lang, B. Estimating the Nutrient Value in Corn and Soybean Stover. In Fact Sheet BL-112; Iowa State University: Ames, IA, USA, 2002.

14. Wyman, C.E.; Hinman, N.D. Fundamentals of production from renewable feedstocks and use as transportation fuel. Appl. Biochem. Biotechnol. 1990, 24/25, 735-753.

15. Schechinger, T.M.; Hettenhaus, J. Corn Stover Harvest: Grower, Custom Operator, and Processor Issues and Answers Iron Horse Custom Farms; US Department of Energy: Oak Ridge, TN, USA, 1999. 
16. Brechbill, S.C.; Tyner, W.E.; Ileleji, K.E. The economics of biomass collection and transportation and its supply to Indiana cellulosic and electric utility facilities. Bioenergy Res. 2011, 4, 141-152.

17. Frear, C.; Zhao, B.; Fu, G.; Richardson, M.; Chen, S.; Fuchs, M.R. An Evaluation of Organic Material Resources for Bioenergy Production in Washington State. In Biomass Inventory and Bioenergy Assessment; Washington State Department of Ecology: Spokane, WA, USA, 2005.

18. Gan, J.; Smith, C.T. Availability of logging residues and potential for electricity production and carbon displacement in the USA. Biomass Bioenergy 2006, 30, 1011-1020.

19. Perlack, R.D.; Wright, L.L.; Turhollow, A.F.; Graham, R.L.; Stokes, B.J.; Erbach, D.C. Biomass as Feedstock for a Bioenergy and Bio Products Industry: The Technical Feasibility of a Billion-Ton Annual Supply. In DTIC Document; U.S. Department of Energy: Oak Ridge, TN, USA, 2005.

20. Sanchez, F.G.; Carter, E.A.; Klepac, J.F. Enhancing the soil organic matter pool through biomass incorporation. Biomass Bioenergy 2003, 24, 337-349.

21. Börjesson, P. Economic evaluation of the environmental impact of logging residue recovery and nutrient compensation. Biomass Bioenergy 2000, 19, 137-152.

22. Gulf Coast CHP Applications Center. Combined Heat and Power Potential Using Texas Agricultural Wastes; Houston Advanced Research Center: The Woodlands, TX, USA, 2008.

23. Viana, H.; Cohen, W.B.; Lopes, D.; Aranha, J. Assessment of forest biomass for use as energy. GIS-based analysis of geographical availability and locations of wood-fired power plants in Portugal. Appl. Energy 2010, 87, 2551-2560.

(C) 2013 by the authors; licensee MDPI, Basel, Switzerland. This article is an open access article distributed under the terms and conditions of the Creative Commons Attribution license (http://creativecommons.org/licenses/by/3.0/). 